\title{
Effect of Epiphytic Fungi on Brown Rot Blossom Blight and Latent Infections in Sweet Cherry
}

\author{
H. P. P. Wittig, K. B. Johnson, and J. W. Pscheidt, Department of Botany and Plant Pathology, Oregon State Uni- \\ versity, 2082 Cordley Hall, Corvallis 97331-2902
}

\begin{abstract}
Wittig, H. P. P., Johnson, K. B., and Pscheidt, J. W. 1997. Effect of epiphytic fungi on brown rot blossom blight and latent infections in sweet cherry. Plant Dis. 81:383-387.

Antagonistic effects of Aureobasidium pullulans, Epicoccum purpurascens, and Gliocladium roseum on establishment of Monilinia fructicola infections on cv. Royal Anne cherry blossoms were assessed in a mist chamber and under field conditions. Conidia of each fungus were applied to blossoms that were subsequently inoculated with conidia of M. fructicola. Mist chamber experiments on forced blossoms demonstrated that incidence of recovery of $M$. fructicola from blossoms was significantly reduced $(P \leq 0.05)$ to similar levels when either $E$. purpurascens or the fungicide benomyl had been applied $24 \mathrm{~h}$ prior to inoculation with M. fructicola. In field trials in 1990, 1991, and 1993, application of E. purpurascens reduced blossom blight relative to nontreated blossoms by 47,58 , and $45 \%$, respectively; whereas application of A. pullulans caused reductions of 54, 13, and 47\%, respectively. Comparable reductions in blossom blight for the fungicide iprodione were 80,95 , and $98 \%$, respectively. Latent $M$. fructicola infections were evaluated by dipping immature green cherries in a dilute solution of the herbicide paraquat. Applications of E. purpurascens and A. pullulans to blossoms reduced the number of latent $M$. fructicola infections in green cherries by 24 and 48\%, respectively, in 1990; 57 and 62\%, respectively, in 1991; and 19 and 16\%, respectively, in 1993. This compares with reductions of 95 , 91 , and $17 \%$ in 1990, 1991, and 1993, respectively, with the fungicide iprodione. E. purpurascens and G. roseum also were recovered from surface-disinfested, paraquat-dipped cherry fruit. Percent recovery of these fungi was significantly $(P \leq 0.05)$ higher from treatments where they had been applied to blossoms compared with the nontreated control.
\end{abstract}

Additional keywords: biological control

Brown rot, caused by Monilinia fructicola (G. Wint.) Honey and Monilinia laxa (Aderhold \& Ruhland) Honey, is an annual disease problem on stone fruits in western Oregon. Infections by M. fructicola and $M$. laxa blight blossoms and twigs, cause cankers on woody tissue, and rot the fruit (5). Management practices for control of brown rot begin with limiting the blossom blight phase of the disease. Source of inoculum for blossom blight is principally conidia released from overwintering fruit mummies and from cankers on twigs blighted the previous season (20).

Latent (quiescent) infections in stone fruits have been reported on apricots, peaches, and plums (11,18,26,29,30,31), and have been suggested to occur in cherry (17). The pathogen becomes latent soon after infection of immature fruit and resumes growth only when the fruit begin to

Corresponding author: K. B. Johnson
E-mail: johnsonk@bcc.orst.edu

This is Oregon State University Technical Paper No. 11,012 .

Accepted for publication 10 January 1997.

Publication no. D-1997-0204-08R

(C) 1997 The American Phytopathological Society mature. Latent infections of apricot and peach are initiated between full bloom and shuck fall $(16,30)$, and can cause significant fruit losses, even during a dry harvest period (30).

Fungicide resistance in the brown rot fungi $(10,13,21,24)$, combined with fewer new fungicide registrations, has accelerated investigations into alternatives for controlling brown rot $(8,14,15)$. The surfaces of aerial plant parts provide a habitat for epiphytic microorganisms, many of which are capable of influencing the growth of pathogens (2). Blossoms are one such habitat that especially favors fungal growth $(3,14,25)$. Fungi may be preferred antagonists for diseases caused by fungal pathogens due to their similarities in habitat requirement and nutrient utilization. Peng and Sutton (23) screened a total of 230 hyphal fungi, yeasts, and bacteria for antagonism of Botrytis cinerea Pers.:Fr., which has a biology similar to that of $M$. fructicola, and found only mycelial fungi were moderately to highly effective in suppressing gray mold of strawberry. A number of studies evaluating fungal antagonists on blossom tissue identified Epicoccum purpurascens Ehrenb. ex Schecht. (syn. E. nigrum Link) as an antagonist of fungal pathogens attacking blossoms $(3,14,15,23,33)$.
The objective of this study was to evaluate the fungal epiphytes Aureobasidium pullulans (de Bary) G. Arnaud, E. purpurascens, and Gliocladium roseum Bainier for their potential to reduce brown rot blossom blight of sweet cherry (Prunus avium L.) caused by $M$. fructicola, and to determine the effect of these epiphytes on the establishment of latent infections. In addition to these fungal epiphytes, $B$. cinerea, a known pathogen of stone fruits $(19,28)$, was evaluated to provide an indication of the effect of competition with M. fructicola on blossoms and to determine the relative pathogenicity of the other epiphytes.

\section{MATERIALS AND METHODS}

Isolates and inoculum preparation. Isolates of $A$. pullulans, $B$. cinerea, and $E$. purpurascens were obtained from healthy peach blossoms plated directly onto potatodextrose agar (Difco Industries, Detroit, MI) containing streptomycin (100 mg/liter) (PDAS). Isolates of $M$. fructicola were obtained from conidia on peach mummies. The isolate of G. roseum was provided by J. Sutton of the University of Ontario.

Conidial inocula of B. cinerea, E. purpurascens, G. roseum, and M. fructicola were prepared by culturing each fungus for 12 to 17 days on PDAS at room temperature. A. pullulans spores were obtained from 4- to 5-day-old cultures grown on PDAS at room temperature. Spore suspensions were prepared by washing conidia from the surface of the medium with distilled water and filtering through two layers of cheesecloth to remove mycelial fragments. Spore concentrations were adjusted with the aid of a hemacytometer. Conidial concentrations sprayed onto blossoms were $1 \times 10^{5}$ spores per $\mathrm{ml}$ for $B$. cinerea and $E$. purpurascens, and 1 to $5 \times$ $10^{6}$ spores per $\mathrm{ml}$ for A. pullulans and $G$. roseum. $M$. fructicola was sprayed onto blossoms at a concentration of $5 \times 10^{4}$ spores per $\mathrm{ml}$.

Mist chamber study. Cherry blossoms from cv. Royal Anne were forced open from dormant branches collected in February 1991 from the OSU Department of Botany and Plant Pathology Field Laboratory, Corvallis, Oregon, and stored at $4^{\circ} \mathrm{C}$. Dormant branches were removed from cold storage and were surface-disinfested in a $0.5 \% \mathrm{NaOCl}$ solution for $90 \mathrm{~s}$. A fresh cut was made on the end of each branch to enhance water uptake. Buckets containing branches with cut ends in water were 
placed in the greenhouse at approximately $20^{\circ} \mathrm{C}$ and covered with plastic bags to reduce desiccation while blossoms opened. After about 2 weeks, four flowering branches 25 to $35 \mathrm{~cm}$ long were placed in florists' foam to represent an experimental unit. A randomized block design was established in the mist chamber with six treatments replicated three times. The six treatments were: 1 , nontreated control; 2 , E. purpurascens; 3, A. pullulans; 4, B. cinerea; 5, benomyl (Benlate 50DF at $0.3 \mathrm{~g}$ a.i./liter); and 6, iprodione (Rovral 50WP at $0.3 \mathrm{~g}$ a.i./liter). Treatments were applied to runoff, using a hand-pump sprayer, to blossoms at full bloom just prior to placement in the mist chamber. Within the chamber, a fine mist was applied to blossoms intermittently for $10 \mathrm{~s}$ at 10 -min intervals. Inoculum of $M$. fructicola was applied to all experimental units $24 \mathrm{~h}$ after application of the biological agents or fungicides. Seven days after inoculation, 12 to 24 blossoms were sampled from each experimental unit and plated individually onto PDAS. Incidence of recovery of $M$. fructicola from blossoms was calculated 4 and 10 days after plating of samples for each treatment and for each replicate.

Field experiments. The effect of $A$. pullulans, B. cinerea, and E. purpurascens on development of blossom blight infection by M. fructicola was tested in field trials in 1990, 1991, and 1993. In 1993, G. roseum also was evaluated. A randomized complete block design with five treatments was used in 1990 and 1991, with four and five replicates, respectively. In 1993, six treatments were used with six replicates. Experimental control treatments included a nontreated control and the fungicide iprodione (Rovral 4F at $1.12 \mathrm{~kg}$ a.i./ha).

Experimental treatments were arranged in a 25-year-old block of sweet cherry cv. Royal Anne located on the OSU Department of Botany and Plant Pathology Field Laboratory, Corvallis. Trees were planted on a $12 \times 6 \mathrm{~m}$ spacing; each experimental unit consisted of half of a tree. Spore suspensions of biological agents were prepared as previously described. For each treatment, 8 liters of a conidial suspension was applied to each unit on each treatment date with a hand-gun sprayer. In 1990, treatments were applied at $50 \%$ full bloom and again at full bloom. In 1991 and 1993, a third spray at petal fall was added. In addition to the protectant sprays, all blossoms also were inoculated with $M$. fructicola $\left(5 \times 10^{4}\right.$ conidia per ml $) 1$ day after the second application of biological agents.

In 1993, blossoms were sampled to evaluate the viability of applied fungi. Twelve blossoms were taken from each tree 8 days following the last application of biological agents and plated individually onto PDAS. Incidence of recovery of applied fungi from plated blossoms was determined.

Epidemics of brown rot blossom blight were measured by making repeated observations on 600 to 800 blossoms per replication treatment. The observed blossoms were located on branches marked for assessment before treatments were applied and considered diseased if $M$. fructicola was seen sporulating on floral or pedicel tissue. In 1990, disease progress curves were developed from observations taken 11,14 , and 18 days following the application of M. fructicola. In 1991, similar curves were developed from observations taken $6,9,11,14$, and 18 days following application of M. fructicola; and in 1993, the observations for disease were taken 3 , $6,9,12,15$, and 18 days following inoculation of the pathogen. Effectiveness of the treatments was determined by plotting percent blossoms blighted over time and then computing the area under the disease progress curve (AUDPC) (12). Additionally, assessments were made approximately 4 weeks before harvest in 1991 and 1993 to determine the effect of bloom treatments on the percentage of blossoms that developed into fruit. Effects of applied epiphytes on development of brown rot fruit rot were not evaluated due to variable and low fruit production.

Latent infections. Establishment of latent $M$. fructicola infections in cherry was evaluated by dipping immature green cher-

Table 1. Incidence of recovery of Monilinia fructicola from "forced open" sweet cherry blossoms treated with spores of epiphytes or fungicides ${ }^{\mathrm{w}}$ and inoculated with conidia of $M$. fructicola ${ }^{\mathrm{x}}$ in a mist chamber

\begin{tabular}{lcc}
\hline Treatment & Concentration & $\begin{array}{c}\text { Incidence of recovery } \\
\text { of } \boldsymbol{M} \text {. fructicola }\end{array}$ \\
\hline Nontreated control & $\ldots$ & $63.9 \mathrm{c}^{\mathrm{z}}$ \\
Epicoccum purpurascens & $10^{5} \mathrm{CFU} / \mathrm{ml}$ & $4.2 \mathrm{a}$ \\
Aureobasidium pullulans & 1 to $5 \times 10^{6} \mathrm{CFU} / \mathrm{ml}$ & $48.3 \mathrm{bc}$ \\
Botrytis cinerea & $10^{5} \mathrm{CFU} / \mathrm{ml}$ & $4.9 \mathrm{a}$ \\
Benomyl & $0.3 \mathrm{~g}$ a.i./liter & $0.0 \mathrm{a}$ \\
Iprodione & $0.3 \mathrm{~g}$ a.i./liter & $27.8 \mathrm{~b}$ \\
\hline w Fungal spore and fungicide suspensions were spray-applied to runoff to blossoms in full bloom. \\
x Conidia of $M$. fructicola were applied 24 h after the application of fungal and fungicide treatments \\
at a rate of $5 \times 10^{4}$ CFU/ml. \\
y Incidence values were transformed to arcsine square root $(x)$ for analysis of variance. Values pre- \\
sented are nontransformed means. \\
${ }^{\mathrm{z}}$ Means followed by the same letter are not significantly different as determined by Fisher's pro- \\
tected least significant difference procedure at $P \leq 0.05$.
\end{tabular}

ries into a dilute solution of the herbicide paraquat (Gramoxone Super, ICI Americas Inc., Wilmington, DE) to induce senescence (6). Symptomless green cherries were collected in the field, 24 to 72 cherries per experimental unit, depending on fruit set. Cherries were surface disinfested for $60 \mathrm{~s}$ in $0.5 \% \mathrm{NaOCl}$, rinsed with sterile distilled water for $60 \mathrm{~s}$, and dipped for 2 min into a solution of filter-sterilized paraquat dichloride at $6 \mathrm{~g}$ a.i./liter of water. Treated cherries were placed into sterile tissue culture wells (24 per plate) and closed in plastic crisper boxes $(26 \times 33 \times$ $10 \mathrm{~cm}$ ). The bottom of each box was lined with moist paper towels to maintain high humidity. Cherries were monitored for expression of $M$. fructicola infections, and final observations were taken after 9 to 12 days of incubation. In 1991 and 1993, additional assessments were made for the incidence of $B$. cinerea, E. purpurascens, and $G$. roseum colonization of green cherries after 12 to 14 days of incubation in the moisture chambers.

Statistical analysis. Dependent variables were subjected to analysis of variance (ANOVA, Gylling Data Management, Inc., Brookings, SD). Proportional incidence data for mist chamber colonization, fruit set, and latent infections were transformed to arcsine square root prior to ANOVA to provide homogeneity of withintreatment variance. Similarly, AUDPC values for blossom blight were $\log (x+1)$ transformed. Criteria for selecting transformations were made by examining residual patterns of data among treatments. Means were compared using the Fisher's protected least significant difference (LSD) procedure at $P \leq 0.05$.

\section{RESULTS}

Mist chamber study. Incidence of recovery of $M$. fructicola from blossoms after the mist treatment was greatest in the nontreated control (Table 1). A significant reduction $(P \leq 0.05)$ in incidence of recovery of $M$. fructicola from blossoms was obtained when the fungi $E$. purpurascens and $B$. cinerea were sprayed on blossoms prior to M. fructicola (93.4 and $92.3 \%$, respectively). Significant reductions in incidence of recovery of $M$. fructicola from blossoms also occurred when blossoms were treated with the fungicides benomyl $(100 \%)$ and iprodione $(56.5 \%)$. Colonization of blossoms by B. cinerea and E. purpurascens was extensive, with collapsed blossoms and spores of these fungi visible on blossom tissue at the time of sampling.

Field experiments. Only the iprodione and $B$. cinerea treatments resulted in significantly lower $(P \leq 0.05)$ incidence of recovery of $M$. fructicola from blossoms compared with the nontreated control (Table 2). Incidence of recovery of each fungal epiphyte from blossoms was highest in treatments where the epiphyte had been applied (Table 2). Incidence of recovery of 
B. cinerea, E. purpurascens, and $G$. roseum from blossoms within their respective treatment averaged 99, 97, and 58\%, respectively. A. pullulans was recovered from $100 \%$ of blossoms to which it was applied, but also was recovered from 99 and $69 \%$ of blossoms treated with iprodione and from the nontreated control, respectively.

In 1990, the fungal treatments E. purpurascens, $A$. pullulans, and $B$. cinerea significantly reduced $(P \leq 0.05)$ the amount of blossom blight compared with the nontreated control (Table 3). For these treatments, reductions in AUDPC values were 47,54 , and $45 \%$, respectively. In 1991, E. purpurascens, A. pullulans, and $B$. cinerea treatments resulted in 58, 13, and $16 \%$ reductions in AUDPC values, respectively, compared with the nontreated control (Table 3), although these values were not significantly different from the control. In 1993, E. purpurascens and $A$. pullulans significantly reduced $(P \leq 0.05)$ the amount of blossom blight compared with the nontreated control. Reductions in AUDPC values for these treatments were 45 and $47 \%$, respectively. In all three years, iprodione significantly reduced $(P \leq$ 0.05 ) the amount of blossom blight compared with the nontreated control.

In 1991 and $1993, B$. cinerea significantly reduced $(P \leq 0.05)$ the percentage of healthy green fruit that developed from blossoms compared with the nontreated control (Table 4). Reductions in percent fruit set due to applications of $B$. cinerea were 50 and $84 \%$, respectively, for 1991 and 1993. In 1993, the G. roseum treatment also reduced fruit set (Table 4).

Latent infections. In 1991, the E. purpurascens and $A$. pullulans treatments significantly $(P<0.05)$ reduced the incidence of latent $M$. fructicola infections by 62 and 57\%, respectively, compared with the nontreated control (Table 5). Similarly, in 1993, treatment with E. purpurascens or $B$. cinerea resulted in significantly fewer $(P \leq 0.05)$ latent $M$. fructicola infections than in the nontreated control. Applications of E. purpurascens and A. pullulans in 1990 also resulted in reduced recovery of $M$. fructicola from green fruit, but the reductions obtained were not significant $(P \geq$ $0.05)$. In all years, incidence of green cherries with latent $M$. fructicola infections was significantly lower $(P \leq 0.05)$ in the iprodione treatment than in the nontreated control.

B. cinerea, E. purpurascens, and $G$. roseum also were recovered from green cherries dipped in paraquat. In 1991, incidence of recovery of $B$. cinerea and $E$. purpurascens averaged 42 and $41 \%$ within their respective treatments compared with 5 and $0.6 \%$, respectively, in the nontreated control (Table 5). In 1993, incidence of recovery of $B$. cinerea, E. purpurascens, and $G$. roseum averaged 39, 26, and 19\% within their respective treatments com- pared with $8,0.6$, and $0.2 \%$, respectively, in the nontreated control.

\section{DISCUSSION}

Blossoms of stone fruits host a number of fungi with the potential to disrupt brown rot infection of blossoms (14). The fungi we isolated from stone fruit blossoms were consistent with the epiphytic mycoflora found on peach twigs and flowers in other studies $(14,27)$. In this study, application of spores of epiphytic fungi to cherry blos- soms reduced brown rot blossom blight in 2 of 3 years of field trials. The level of control, however, was not equivalent to control achieved using fungicides. The most consistent and effective antagonistic fungi tested were $A$. pullulans and E. purpurascens. Field trials applying $G$. roseum to blossoms showed little promise for control of blossom blight.

E. purpurascens was reported to be an antagonist of $M$. laxa in peach blossoms in Spain (14). This fungus also was shown to

Table 2. Incidence of recovery of fungi from sweet cherry blossoms ${ }^{\mathrm{x}}$ in the field following application of epiphytes and fungicides in 1993

\begin{tabular}{|c|c|c|c|c|c|}
\hline \multirow[b]{2}{*}{ Treatment $^{y}$} & \multicolumn{5}{|c|}{ Recovery $(\%)^{\mathbf{z}}$} \\
\hline & $\begin{array}{l}\text { Monilinia } \\
\text { fructicola }\end{array}$ & $\begin{array}{c}\text { Epicoccum } \\
\text { purpurascens }\end{array}$ & $\begin{array}{c}\text { Aureobasidium } \\
\text { pullulans }\end{array}$ & $\begin{array}{l}\text { Botrytis } \\
\text { cinerea }\end{array}$ & $\begin{array}{l}\text { Gliocladium } \\
\text { roseum }\end{array}$ \\
\hline Nontreated control & 68.8 & 6.5 & 68.9 & 32.5 & 4.2 \\
\hline Epicoccum purpurascens & 48.6 & 97.2 & 26.4 & 18.1 & 1.2 \\
\hline Aureobasidium pullulans & 57.0 & 27.8 & 100.0 & 41.7 & 1.4 \\
\hline Botrytis cinerea & 17.0 & 3.0 & 49.6 & 98.5 & 0.0 \\
\hline Gliocladium roseum & 64.5 & 4.2 & 73.7 & 43.3 & 58.4 \\
\hline Iprodione & 0.0 & 0.0 & 98.6 & 16.7 & 22.2 \\
\hline $\operatorname{LSD}(P=0.05)$ & 21.5 & 15.7 & 19.1 & 15.9 & 14.2 \\
\hline
\end{tabular}

${ }^{\mathrm{x}}$ Cherry blossoms were sampled 8 days following the full bloom application of fungal epiphytes and fungicides.

y Treatments were applied to runoff at $50 \%$ full bloom, full bloom, and petal fall.

${ }^{\mathrm{z}}$ Percentage of blossoms on which specified fungi were detected, based on 72 blossoms (12 blossoms per replicate) plated directly onto potato-dextrose agar plus streptomycin.

Table 3. Area under the disease progress curve (AUDPC) for brown rot blossom blight in sweet cherry for 1990, 1991, and 1993 field trials ${ }^{v}$

\begin{tabular}{lcccc}
\hline & & \multicolumn{3}{c}{ AUDPC $^{\mathbf{x}}$} \\
\cline { 3 - 5 } Treatment $^{\mathbf{w}}$ & Concentration & $\mathbf{1 9 9 0}$ & $\mathbf{1 9 9 1}$ & $\mathbf{1 9 9 3}$ \\
\hline Nontreated Control & & $0.10 \mathrm{c}^{\mathrm{y}}$ & $0.54 \mathrm{~b}$ & $3.51 \mathrm{c}$ \\
Epicoccum purpurascens & $10^{5} \mathrm{CFU} / \mathrm{ml}$ & $0.05 \mathrm{~b}$ & $0.23 \mathrm{ab}$ & $1.92 \mathrm{~b}$ \\
Aureobasidium pullulans & 1 to $5 \times 10^{6} \mathrm{CFU} / \mathrm{ml}$ & $0.04 \mathrm{ab}$ & $0.47 \mathrm{~b}$ & $1.87 \mathrm{~b}$ \\
Botrytis cinerea & $10^{5} \mathrm{CFU} / \mathrm{ml}$ & $0.05 \mathrm{~b}$ & $0.46 \mathrm{~b}$ & $2.20 \mathrm{bc}$ \\
Gliocladium roseum & 1 to $5 \times 10^{6} \mathrm{CFU} / \mathrm{ml}$ & $\ldots . \mathrm{z}^{\mathrm{a}}$ & $\ldots$ & $3.15 \mathrm{c}$ \\
Iprodione & $1.12 \mathrm{~kg}$ a.i.//ha & $0.02 \mathrm{a}$ & $0.03 \mathrm{a}$ & $0.06 \mathrm{a}$ \\
\hline
\end{tabular}

${ }^{\mathrm{v}}$ Conidia of $M$. fructicola were applied to runoff 1 day after the full bloom treatments of epiphytes and fungicides at a concentration $5 \times 10^{4} \mathrm{CFU} / \mathrm{ml}$.

${ }^{\mathrm{w}}$ Fungal and fungicide treatments were applied to runoff at 50\% full bloom and full bloom in 1990, and at 50\% full bloom, full bloom, and petal fall in 1991 and 1993 .

${ }^{\mathrm{x}}$ AUDPC values were transformed to $\log (x+1)$ for analysis of variance. Values presented are nontransformed means.

${ }^{y}$ Means followed by the same letter are not significantly different as determined by Fisher's protected least significant difference procedure at $P \leq 0.05$.

${ }^{\mathrm{z}}$ Not tested in 1990 and 1991.

Table 4. Influence of fungal epiphytes applied to sweet cherry blossoms ${ }^{\mathrm{w}}$ on percentage of blossoms that developed fruit in 1991 and 1993 field trials

\begin{tabular}{lccc}
\hline & & \multicolumn{2}{c}{ Fruit set $^{(\%)^{\mathbf{x}}}$} \\
\cline { 3 - 4 } Treatment & Concentration & $\mathbf{1 9 9 1}$ & $\mathbf{1 9 9 3}$ \\
\hline Nontreated control & & $22.6 \mathrm{a}^{\mathrm{y}}$ & $8.9 \mathrm{a}$ \\
Epicoccum purpurascens & $10^{5} \mathrm{CFU} / \mathrm{ml}$ & $27.8 \mathrm{a}$ & $8.6 \mathrm{a}$ \\
Aureobasidium pullulans & 1 to $5 \times 10^{6} \mathrm{CFU} / \mathrm{ml}$ & $20.8 \mathrm{ab}$ & $5.7 \mathrm{ab}$ \\
Botrytis cinerea & $10^{5} \mathrm{CFU} / \mathrm{ml}$ & $11.2 \mathrm{~b}$ & $1.4 \mathrm{c}$ \\
Gliocladium roseum & 1 to $5 \times 10^{6} \mathrm{CFU} / \mathrm{ml}$ & $\ldots .3 \mathrm{~b}$ \\
Iprodione & $1.12 \mathrm{~kg}$ a.i./ha & $28.3 \mathrm{a}$ & $10.4 \mathrm{a}$ \\
\hline w Fungal and fungicide treatments were applied to runoff at $50 \%$ full bloom, full bloom, and petal \\
fall. \\
x Incidence values were transformed to arcsine square root $(x)$ for analysis of variance. Values pre- \\
sented are nontransformed means. \\
y Means followed by the same letter are not significantly different as determined by Fisher's pro- \\
tected least significant difference procedure at $P \leq 0.05$.
\end{tabular}


Table 5. Incidence of recovery of fungi from green cherries ${ }^{u}$ dipped in the herbicide paraquat in 1990, 1991, and 1993 field trials

\begin{tabular}{|c|c|c|c|c|c|c|c|c|}
\hline \multirow[b]{2}{*}{ Treatment ${ }^{v, w}$} & \multicolumn{3}{|c|}{ Monilinia fructicola $^{\mathrm{x}}$} & \multicolumn{2}{|c|}{ Botrytis cinerea } & \multicolumn{2}{|c|}{ Epicoccum purpurascens } & \multirow{2}{*}{$\begin{array}{c}\text { Gliocladium } \\
\text { roseum } \\
1993\end{array}$} \\
\hline & 1990 & 1991 & 1993 & 1991 & 1993 & 1991 & 1993 & \\
\hline Nontreated control & $24.0 \mathrm{~b}^{\mathrm{y}}$ & $58.6 \mathrm{c}$ & $74.7 \mathrm{bc}$ & $5.0 \mathrm{~b}$ & $7.6 \mathrm{~b}$ & $0.6 \mathrm{c}$ & $0.6 \mathrm{~b}$ & $0.2 \mathrm{~b}$ \\
\hline Epicoccum purpurascens & $18.3 \mathrm{~b}$ & $25.1 \mathrm{~b}$ & $60.3 \mathrm{a}$ & $4.7 \mathrm{~b}$ & $2.7 \mathrm{~b}$ & $40.6 \mathrm{a}$ & $25.9 \mathrm{a}$ & $2.8 \mathrm{~b}$ \\
\hline Aureobasidium pullulans & $12.5 \mathrm{~b}$ & $22.2 \mathrm{ab}$ & $62.7 \mathrm{ab}$ & $5.0 \mathrm{~b}$ & $8.8 \mathrm{~b}$ & $8.7 \mathrm{~b}$ & $0.9 \mathrm{~b}$ & $1.2 \mathrm{~b}$ \\
\hline Botrytis cinerea & $11.5 \mathrm{~b}$ & $37.2 \mathrm{bc}$ & $60.6 \mathrm{a}$ & $48.1 \mathrm{a}$ & $39.4 \mathrm{a}$ & $0.3 \mathrm{c}$ & $0.7 \mathrm{~b}$ & $0.0 \mathrm{~b}$ \\
\hline Gliocladium roseum & $\ldots{ }^{\mathrm{z}}$ & $\ldots$ & $82.0 \mathrm{c}$ & $\ldots$ & $4.2 \mathrm{~b}$ & $\ldots$ & $0.4 \mathrm{~b}$ & $19.1 \mathrm{a}$ \\
\hline Iprodione & $1.1 \mathrm{a}$ & $5.3 \mathrm{a}$ & $62.2 \mathrm{a}$ & $8.3 \mathrm{~b}$ & $8.3 \mathrm{~b}$ & $1.1 \mathrm{bc}$ & $0.6 \mathrm{~b}$ & $0.4 \mathrm{~b}$ \\
\hline
\end{tabular}

u Symptomless green cherries, 24 to 72 per replicate, were sampled, with four, five, and six replicates for 1990, 1991, and 1993, respectively. Cherries, following surface-disinfection, were dipped into a dilute solution of the herbicide paraquat to induce senescence and initiate expression of latent infections.

v Fungal and fungicide treatments were applied to runoff at 50\% full bloom and full bloom in 1990, and at $50 \%$ full bloom, full bloom, and petal fall in 1991 and 1993.

${ }^{\text {w }}$ The rate of iprodione was $1.12 \mathrm{~kg}$ a.i./ha. The spore concentration for $B$. cinerea and E. purpurascens was $10^{5} \mathrm{CFU} / \mathrm{ml}$, and the spore concentration for A. pullulans and $G$. roseum was 1 to $5 \times 10^{6} \mathrm{CFU} / \mathrm{ml}$.

$\mathrm{x}$ Incidence values were transformed to arcsine square root $(x)$ for analysis of variance. Values presented are nontransformed means.

y Means followed by the same letter are not significantly different as determined by Fisher's protected least significant difference procedure at $P \leq 0.05$.

${ }^{\mathrm{z}}$ G. roseum was not included in experiments done in 1990 and 1991.

antagonize a number of other pathogens $(3,22,27,33)$. Its effect may be due, in part, to the production of antifungal compounds $(1,4,27)$. Rapid colonization of blossom tissue by $E$. purpurascens was reported on bean flowers (34). In the mist chamber study, under conditions of extreme humidity, blossom colonization by E. purpurascens was evident with visible sporulation observed within a week of its application to blossoms. This ability to colonize blossom tissue also was observed in the high level of recovery of E. purpurascens from cherry blossoms and in 2 years of studies done on peach blossoms (32), as well as from green fruit treated with this fungus. The ability of E. purpurascens to compete with $M$. fructicola on blossom tissue may also be partially responsible for the decrease in the number of latent $M$. fructicola infections on fruit where blossoms were treated with $E$. purpurascens.

$B$. cinerea, although a known pathogen of stone fruits $(19,28)$, was chosen as a comparative antagonist because we judged its ability to colonize floral tissues to be intermediate to that of $M$. fructicola and $E$. purpurascens. B. cinerea showed potential to reduce incidence of recovery of $M$. fructicola on blossoms in mist chamber studies, and it also caused necrosis of the blossoms. Despite this demonstrated ability to colonize blossoms in the mist chamber, applications of $B$. cinerea to blossoms did not consistently result in significant reductions in brown rot blossom blight or latent infections of $M$. fructicola on fruit compared with the nontreated control. B. cinerea caused significant reductions in fruit set of cherry, whereas fruit set for other epiphyte treatments, except for G. roseum, were statistically similar to the nontreated control.

Limiting the activity of the pathogen during bloom is important in reducing the incidence of latent $M$. fructicola infections in green cherries. Fungicide applications during bloom significantly reduced $(P \leq$ $0.05)$ the incidence of latent $M$. fructicola infections in all three field trials, while $E$. purpurascens caused significant reductions in 2 of 3 years. Recovery of epiphytes from paraquat-dipped cherries was not anticipated and indicates that a number of fungi other than M. fructicola may be capable of causing latent infections. Dugan and Roberts (9) observed the establishment of fruit infections by resident epiphytes and detected their presence soon after petal fall. They hypothesized that postharvest losses may be caused by the resumption of growth of these fungi, including A. pullulans and E. purpurascens, in stored cherries grown in production areas where infection by $M$. fructicola does not commonly occur.

Among seasons, the severity of brown rot blossom blight epidemics was influenced by the amount of precipitation occurring during bloom. Rainfall during the month of April was 59, 91, and $162 \mathrm{~mm}$ in 1990, 1991, and 1993, respectively. The excessive rainfall of 1993 may explain why the normally effective fungicide treatment, iprodione, failed to prevent establishment of latent $M$. fructicola infections in this season.

Fungicides can affect nontarget organisms by altering the number and diversity of fungi residing on blossoms to those fungi more tolerant to the fungicides used. The implications of these shifts are unclear. Research is needed to determine if long-term use of a fungicide changes the overall balance of resident fungi in a way that reduces the potential for these natural epiphytes to have a role in limiting infections by $M$. fructicola.

Biological control on the phylloplane requires the use of microorganisms adapted to grow on the same part of the plant where the pathogen establishes an infection. In general, antagonists should possess an ability to compete, produce antibiotics, parasitize the pathogen, or have some combination of these traits (7). In the case of brown rot, these organisms can influence disease development by reducing partially the proportion of blossoms blighted by $M$. fructicola or the establishment of latent infections. A. pullulans and $E$. purpurascens reduced the amount of brown rot blossom blight caused by $M$. fructicola in two of three seasons, and their application also may reduce the amount of inoculum available to fruit rot. The ability of these fungi to establish latent infections in cherry fruit that could affect postharvest quality, however, may limit their potential as biological control organisms.

\section{ACKNOWLEDGMENTS}

The research was supported by the Western Region Pesticide Impact Assessment Program and the Oregon Agricultural Experiment Station. We thank J. Stone for assistance with fungal identification and L. Tate for technical assistance in the orchard.

\section{LITERATURE CITED}

1. Bamford, P. C., Norris, G. L. F., and Ward, G. 1961. Flavipin production by Epicoccum spp. Trans. Br. Mycol. Soc. 44:354-356.

2. Blakeman, J. P., and Fokkema, N. J. 1982. Potential for biological control of plant diseases on the phylloplane. Annu. Rev. Phytopathol. 20:167-192.

3. Boland, G. J., and Inglis, G. D. 1989. Antagonism of white mold (Sclerotinia sclerotiorum) of bean by fungi from bean and rapeseed flowers. Can. J. Bot. 67:1775-1781.

4. Brown, A. E., Finlay, R., and Ward, J. S 1987. Antifungal compounds produced by Epicoccum purpurascens against soil-borne plant pathogenic fungi. Soil Biol. Biochem. 19:657-664.

5. Byrde, R. J. W., and Willets, H. J. 1977. The brown rot fungi of fruit. Pergamon Press, New York.

6. Cerkauskas, R. F., and Sinclair, J. B. 1980 Use of paraquat to aid detection of fungi in soybean tissues. Phytopathology 70:10361038.

7. Cook, R. J., and Baker, K. F. 1983. The nature and practice of biological control of plant pathogens. American Phytopathological Society, St. Paul, MN

8. De Cal, A., M.-Sagasta, E., and Melgarejo, P. 1990. Biological control of peach twig blight (Monilinia laxa) with Penicillium frequentans. Plant Pathol. 39:612-618.

9. Dugan, F. M., and Roberts, R. G. 1994. Etiology of preharvest colonization of Bing cherry fruit by fungi. Phytopathology 84:1031-1036. 
10. Elmer, P. A. G., and Gaunt, R. E. 1986. A survey of fungicide insensitivity in Monilinia fructicola. Proc. N.Z. Weed Pest Control Conf., 39th. 39:166-169.

11. Jenkins, P. T., and Reinganum, C. 1965. The occurrence of a quiescent infection of stone fruits caused by Sclerotinia fructicola (Wint.) Rehm. Aust. J. Agric. Res. 16:131-140.

12. Johnson, K. B., Teng, P. S., and Radcliffe, E. B. 1987. Analysis of potato foliage losses caused by interacting infestations of early blight, Verticillium wilt, and potato leafhopper; and the relationship to yield. Z. Pflanzenkrankh. Pflanzenschutz 94:22-33.

13. Jones, A. L., and Ehret, G. R. 1976. Isolation and characterization of benomyl tolerant strains of Monilinia fructicola. Plant Dis. Rep. 60:765-769.

14. Melgarejo, P., Carrillo, R., and M.-Sagasta, E. 1985. Mycoflora of peach twigs and flowers and its possible significance in biological control of Monilinia laxa. Trans. Br. Mycol. Soc. 85:313-317.

15. Melgarejo, P., Carrillo, R., and M.-Sagasta, E. 1986. Potential for biological control of Monilinia laxa in peach twigs. Crop Prot. 5:422-426

16. Morschel, J. R. G. 1955. Brown rot of stone fruits in New South Wales. II. Some observations and trials on the Murrumbidgee irrigation areas. Agric. Gaz. N.S.W. 66:146-150.

17. Northover, J., and Biggs, A. R. 1990. Susceptibility of immature and mature sweet and sour cherries to Monilinia fructicola. Plant Dis. 74:280-284.

18. Northover, J., and Cerkauskas, R. F. 1994.
Detection and significance of symptomless latent infections of Monilinia fructicola in plums. Can. J. Plant Pathol. 16:30-36.

19. Ogawa, J. M., and English, H. 1960. Blossom blight and green fruit rot of almond, apricot and plum caused by Botrytis cinerea. Plant Dis. Rep. 44:265-268.

20. Ogawa, J. M., and English, H. 1991. Diseases of temperate zone tree fruit and nut crops. University of California, Division of Agriculture and Natural Resources, Oakland.

21. Ogawa, J. M., Manji, B. T., Bostock, R. M., Canez, V. M., and Bose, E. A. 1984. Detection and characterization of benomylresistant Monilinia laxa on apricots. Plant Dis. 68:29-31.

22. Pace, M. A., and Campbell, R. 1974. The effect of saprophytes on infection of leaves of Brassica spp. by Alternaria brassicicola. Trans. Br. Mycol. Soc. 63:193-196.

23. Peng, G., and Sutton, J. C. 1990. Biological methods to control grey mould of strawberry. Pages 233-240 in: Proc. Brighton Crop Prot. Conf. -Pests Dis., Brighton, England.

24. Penrose, L. J., Koffmann, W., and Nicholls, M. R. 1985. Field occurrence of vinclozolin resistance in Monilinia fructicola. Plant $\mathrm{Pa}-$ thol. 34:228-234

25. Raymond, F. L., Etchells, J. L., Bell, T. A., and Masley, P. M. 1959. Filamentous fungi from blossoms, ovaries, and fruit of pickling cucumbers. Mycologia 51:492-511.

26. Rosenberger, D. A. 1985. Observations on quiescent brown rot infections in grand prize plums. Pages 19-22 in: Proc. Brown Rot Stone Fruit Workshop, Ames, Iowa, 1983. T.
J. Burr, ed. New York State Agricultural Experiment Station, Geneva

27. Royse, D. J., and Ries, S. M. 1978. The influence of fungi isolated from peach twigs on the pathogenicity of Cytospora cincta. Phytopathology 68:603-607.

28. Shotwell, K. M., and Ogawa, J. M. 1984 Botrytis blossom blight and fruit rot of sweet cherry (Prunus avium) and their control using fungicides. (Abstr.) Phytopathology 74:1141.

29. Tate, K. G., and Corbin, J. B. 1978. Quiescent fruit infections of peach, apricot, and plum in New Zealand caused by the brown rot fungus Sclerotinia fructicola. N.Z. J. Exp. Agric. 6:319-325

30. Wade, G. C. 1956. Investigations on brown rot of apricots caused by Sclerotinia fructicola (Wint.) Rehm. I. The occurrence of latent infection in fruit. Aust. J. Agric. Res. 7:504515.

31. Wade, G. C., and Cruickshank, R. H. 1992 The establishment and structure of latent infections with Monilinia fructicola on apricots. J. Phytopathol. 136:95-106.

32. Wittig, H. P. P. 1992. Effect of resident epiphytic fungi on development of brown rot blossom blight of stone fruits. M.S. thesis. Oregon State University, Corvallis.

33. Zhou, T., and Reeleder, R. D. 1989. Application of Epicoccum purpurascens spores to control white mold of snap bean. Plant Dis. 73:639-642.

34. Zhou, T., and Reeleder, R. D. 1991. Colonization of bean flowers by Epicoccum purpurascens. Phytopathology 81:774-778. 